\title{
Antioxidant status and glutathione metabolism in peripheral blood mononuclear cells from patients with chronic hepatitis $\mathbf{C}$
}

\author{
Patricia Boya, Andrés de la Peña, Oscar Beloqui, Esther Larrea, Marian Conchillo, Yurdana Castelruiz, \\ Maria-Pilar Civeira and Jesús Prieto \\ Department of Internal Medicine and Liver Unit, University Clinic, University of Navarra, Pamplona, Spain
}

\begin{abstract}
Background/Aims: Oxidative stress could play a role in the pathogenesis of hepatitis $\mathrm{C}$ virus infection. We investigated the oxidant/antioxidant status in peripheral blood mononuclear cells from patients with chronic hepatitis $\mathbf{C}$ and controls.

Methods/Results: Lipid peroxidation products and superoxide dismutase activity in peripheral blood mononuclear cells were higher in chronic hepatitis $\mathrm{C}$ patients than in healthy subjects while glutathione Stransferase activity was reduced in patients as compared to controls. Catalase, glutathione peroxidase and glutathione reductase were similar in chronic hepatitis $C$ and normal individuals. No statistically significant differences were found between patients and controls with regard to glutathione levels in peripheral blood mononuclear cells, but $35 \%$ of patients
\end{abstract}

G LUTATHIONE (GSH), the most abundant non-enzymatic antioxidant present in cells, plays an important role in the defense against oxidative-stress-induced cell injury (1). Cells of the immune system are exposed during inflammatory processes to large amounts of reactive oxygen intermediates, and thus need an efficient glutathione system to neutralize free radicals, which could otherwise disturb immune functions $(2,3)$. In cells glutathione is present mainly in its reduced form. Reduced GSH can be converted to oxidized glutathione (GSSG), which is revertible to the reduced form with the enzyme glutathione reductase (GR). Glutathione reductase is a widespread flavoprotein that accounts for the very high GSH/GSSG ratios

Received 17 February; revised 1 April; accepted 7 May 1999

Correspondence: Jesús Prieto, Department of Internal Medicine and Liver Unit, University Clinic, University of Novarra, Pamplona, Spain.

Fax: 34948 296785. e-mail: jprieto@unav.es with chronic hepatitis $\mathbf{C}$ showed values of glutathione and oxidized glutathione which were below and above, respectively, the limits of normal controls. Finally, the glutathione synthetic capacity of the cytosol of peripheral blood mononuclear cells was significantly higher in patients than in controls, indicating increased glutathione turnover in lymphocytes from patients with chronic hepatitis $C$.

Conclusions: Oxidative stress is observed in peripheral blood mononuclear cells from chronic hepatitis $\mathbf{C}$ patients. This process might alter lymphocyte function and facilitate the chronicity of the infection.

Key words: Antioxidant enzymes; Glutathione; Hepatitis C virus; Malondialdehyde; Oxidative stress.

found in cells $(1,4)$. GSH can be synthesized de novo from precursor aminoacids by two ATP-dependent cytosolic reactions catalyzed by $\gamma$-glutamyl cysteine synthetase $(\gamma$-GCS) and glutathione synthetase (1).

Cells are also equipped with enzymatic antioxidant mechanisms that play an important role in the elimination of free radicals. Superoxide dismutase (SOD), catalase and glutathione peroxidase (GPX) are enzymes involved in the clearance of superoxide and hydrogen peroxide $\left(\mathrm{H}_{2} \mathrm{O}_{2}\right)$. SOD catalyzes the dismutation of superoxide into $\mathrm{H}_{2} \mathrm{O}_{2}$, which has to be eliminated by GPX and/or catalase (5). Another important antioxidant enzymatic system is represented by isoenzymes of glutathione S-transferase (GST). These enzymes catalyze the conjugation of GSH with toxic compounds, to generate glutathione S-conjugates which are excreted outside the cell (6). GSTs are also known to be involved, the protection of cellular membranes by neutralizing lipid hydroperoxides using reduced GSH as a cofactor $(4,7)$. 
Hepatitis $\mathrm{C}$ virus (HCV) is the main causative agent of chronic viral hepatitis. Chronic hepatitis $\mathrm{C}$ (CH-C) can progress to cirrhosis and eventually to hepatocellular carcinoma over a period of $20-30$ years. The mechanisms by which HCV causes cell damage are not well understood. Different mechanisms including immunological liver damage, direct cytotoxicity mediated by different viral products and induction of oxidative stress have been suggested as playing a pathogenic role in this infection (8). Oxidative liver injury has been proposed in chronic hepatitis $\mathrm{C}$, as increased levels of lipid peroxidation products (such as malondialdehyde, MDA) are found in both serum (9) and liver (10-12) from $\mathrm{CH}-\mathrm{C}$ patients compared to healthy controls. Also, administration of $\mathrm{N}$-acetyl-cysteine in addition to interferon (IFN) facilitates the biochemical response to this antiviral drug in IFN-resistant $\mathrm{CH}-\mathrm{C}$ patients (13).

Hepatitis $\mathrm{C}$ virus infects hepatocytes as well as lymphoid cells $(14,15)$. In previous work $(16)$ we have found increased mRNA levels of manganese-dependent SOD (Mn-SOD) in peripheral blood mononuclear cells (PBMC) from patients with chronic HCV infection, suggesting that oxidative stress might be present in peripheral lymphocytes in this condition. Since the therapeutic response to IFN depends critically on the ability of this compound to stimulate an efficient antiviral immune response $(17,18)$, and oxidative stress is known to impair the effector functions of lymphocytes (3), we decided to investigate further the presence of oxidative stress in PBMC from HCV-infected individuals. We therefore determined MDA, GSH and GSSG levels, GSH synthetic capability, mRNA expression for $\gamma$-GCS, and the activities of SOD, catalase, GPX, GR and GST in peripheral blood mononuclear cells from patients with chronic hepatitis $\mathrm{C}$ and healthy controls.

\section{Materials and Methods}

\section{Patients}

Because of the excessive amount of blood needed for all the laboratory procedures included in the present study, two different cohorts of patients were analyzed. Written consent was obtained in all cases.

The first cohort comprised 20 patients with $\mathrm{CH}-\mathrm{C}$ ( 11 males and 9 females, age range from 31 to 79 years; 3 cases showed liver cirrhosis and 18 were infected with genotype $1 \mathrm{~b}$ ). All the patients from this cohort were non-responders to IFN treatment (19). In this cohort we measured the antioxidant enzyme activities and MDA levels.

In the second cohort we determined oxidized and reduced GSH levels, GSH synthetic capability, and the expression of $\gamma$-GCS. This group included 29 patients with chronic hepatitis $C$ ( 21 males and 8 females, age range from 23 to 67 years; 2 patients had liver cirrhosis and 20 cases were infected with genotype $1 \mathrm{~b}$ ). In this cohort 19 patients were non-responders to IFN treatment, 5 patients had never received IFN treatment, and the rest showed partial biochemical or virological responses to IFN.

Both cohorts were comparable with regard to disease activity and had similar levels of albumin, bilirubin, $\gamma$ GT, AST and ALT $(3.9 \pm 0.1$ $\mathrm{g} / \mathrm{dl}, 0.81 \pm 0.05 \mathrm{mg} / \mathrm{dl}, 34.1 \pm 5.0 \mathrm{U} / 1,51.9 \pm 14.1 \mathrm{U} / \mathrm{l}$ and $82.3 \pm 15.5$
$\mathrm{U} / 1$, respectively for cohort 1 and $4.2 \pm 0.1,0.69 \pm 0.07,35.8 \pm 5.0$, $45.2 \pm 4.1$ and $81.6 \pm 8.3$ for cohort 2 ; not significant (ns) for all variables when comparing the two cohorts). Biochemical parameters were also similar in the subsets of patients within each cohort who were subjected to different analytical determinations (data not shown).

A group of 24 healthy volunteers (10 males and 14 females, ages 26 to 72) served as controls for the first cohort, and 35 healthy volunteers ( 17 males and 18 females, from 20 to 67 years of age) served as controls for the second cohort. Both groups of controls were comparable in age and sex.

In all cases the diagnosis of chronic hepatitis $\mathrm{C}$ was based on raised serum transaminases for at least 6 months, positivity for anti-HCV antibodies (ELISA Second Generation, Ortho Diagnostic System, USA), and the presence of HCV-RNA by reverse transcription-PCR in serum (19). HCV detection, quantitation and genotyping were performed as previously described $(16,19)$. Histological evidence of chronic hepatitis was assessed in all cases. None of the patients had received interferon treatment for at least 3 months prcvious to the study.

Isolation of PBMC and preparation of cytosol

Blood was collected in heparinized tubes from the patients after an overnight fast, and PBMC were isolated as previously described (20). Less than $30 \mathrm{~min}$ elapsed between the blood extraction and PBMC isolation. All steps from this point were carried out at $4^{\circ} \mathrm{C}$. For MDA and antioxidant enzyme activities, cytosolic extracts from $20 \times 10^{6}$ PBMC were prepared essentially as described (21). Cells were allowed to swell up for $20 \mathrm{~min}$ in cold buffer A (10 mM HEPES pH 7.9, 10 $\mathrm{mM} \mathrm{KCl}, 0.1 \mathrm{mM}$ EGTA, $1 \mathrm{mM}$ dithiothreitol, $0.5 \mathrm{mM}$ PMSF) and disrupted by vortexing after Nonidet-P40 addition. Nuclei were pelleted by centrifugation $\left(30 \mathrm{~s}\right.$ at $\left.15000 \mathrm{~g}, 4^{\circ} \mathrm{C}\right)$ and cytosolic extract was cleared by centrifugation $\left(5 \mathrm{~min}\right.$ at $15000 \mathrm{~g}, 4^{\circ} \mathrm{C}$ ).

In the experiments involving GSH determinations, isolated PBMC were disrupted by ultrasonation (Sonifier 250, Branson, USA) in two 10 -s sessions. The cytosolic fraction was purified by ultracentrifugation at $100000 \mathrm{~g}$ for $1 \mathrm{~h}$ at $4^{\circ} \mathrm{C}$. One aliquot of the supernatant was used for total glutathione determinations and for GSH/GSSG quantification. Another aliquot of cytosol was used to measure GSH synthetic capability. Total protein concentration in cytosols was determined using the Bio-Rad protein assay (Bio-Rad Laboratories, USA) using BSA standards. All samples were stored at $-80^{\circ} \mathrm{C}$.

\section{Lipid peroxidation}

MDA in PBMC was used as an index of lipid peroxidation. Determinations were performed using the colorimetric assay for lipid peroxidation Bioxytech ${ }^{\mathbb{B}}$ LPO-586 (Oxis International, France), which after reacting with MDA, generates a stable chromophore that was measured at $586 \mathrm{~nm}$ in a Hitachi U2000 Spectro (Boehringer Mannheim, Germany).

\section{Activity of antioxidant enzymes}

SOD, catalase, GR, GPX, and GST activities in cytosolic extract from PBMC were spectrophotometrically measured in a Cobas Mira (Roche Diagnostica, Switzerland) as previously described (22). Briefly, SOD (E.C.1.15.1.1) activity was determined at $37^{\circ} \mathrm{C}$ with the commercially available kit "Ransod" (Randox, UK), adapted to the Cobas Mira. Catalase (E.C.1.11.1.6) activity was determined at $25^{\circ} \mathrm{C}$ according to the method of Goth (23). GR (E.C.1.6.4.2) activity was also measured with the "Glutathione Reductase" package (Randox, UK) also adapted to a Cobas Mira autoanalyzer. GPX (E.C1.11.1.9) was determined at $37^{\circ} \mathrm{C}$ with the commercial kit "Ransel" (Randox, UK), using the Cobas Mira autoanalyzer. GST (E.C.2.5.1.18) was colorimetrically determined in the Cobas Mira at $340 \mathrm{~nm}(6)$.

\section{Total glutathione and reduced and oxidized fractions}

Total glutathione was measured according to Tietze (24). The method is based on the reaction with dithionitrobenzoic acid (DTNB) in the presence of glutathione-reductase and NADPH. Absorbances at 420 $\mathrm{nm}$ from each sample were interpolated in a GSH standard curve, and glutathione concentrations were expressed as $\mathrm{nmol} / \mathrm{mg}$ protein. 


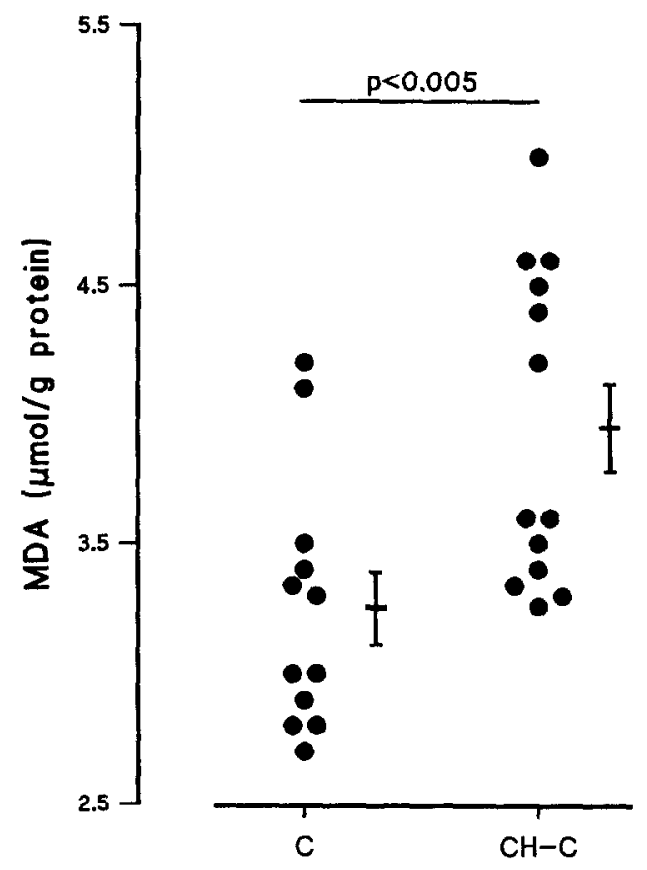

Fig. 1. Malondialdehyde (MDA) levels in peripheral blood mononuclear cells from chronic hepatitis $\mathrm{C}(\mathrm{CH}-\mathrm{C}) \mathrm{pa}-$ tients and healthy controls (C).

PBMC cytosolic fraction from $\mathrm{HCV}$-infected patients and healthy controls was used to quantify, by high pressure liquid chromatography (HPLC), GSH and GSSG following a method previously described (25) with slight modifications (26). Briefly, $300 \mu \mathrm{l}$ of the cytosolic fraction obtained as indicated above were immediately derivatized using 1-fluoro-2,4-dinitrobenzene. Samples were then chromatographed on a 3-aminopropyl-Spherisorb, $20 \mathrm{~cm} \times 4.6 \mathrm{~mm}, 5 \mu \mathrm{m}$ HPLC column, equilibrated in $80 \%$ methanol. Elution was performed with $0.5 \mathrm{M}$ sodium acetate in $64 \%$ methanol and followed at $365 \mathrm{~nm}$.

\section{GSH synthetic rate}

PBMC cytosols from HCV-infected patients and controls were dialyzed overnight at $4^{\circ} \mathrm{C}$ to deplete cytosolic GSH content in order to minimize feedback inhibition of $\gamma$-GCS by GSH. The capacity to synthesize glutathione was determined using monochlorobimane $(\mathrm{mBCl})$ as described by Fernández-Checa \& Kaplowitz (27). Monochlorobimane binds GSH specifically in a reaction catalyzed by the enzyme glutathione S-transferase. GSH-mBCl adducts were measured by a fluorimetric technique, in a Perkin Elmer Luminiscence Spectrophotometer LS-50B (Perkin Elmer, USA), with excitation at $392 \mathrm{~nm}$ and emission at $477 \mathrm{~nm}$, with a slit width of $3.0 \mathrm{~nm}$ for both excitation and emission monochromators. The GSII synthetic rate is defined as the net increase in the fluorescence signal (slope per minute) obtained by subtracting the fluorescence signal per minute in the pres- ence of buthionine-sulfoximine (BSO) from that in the absence of BSO. This compound irreversibly inhibits $\gamma$-GCS, the limiting step in de novo GSH synthesis. The difference in fluorescence per minute was converted to concentration of GSH using the GSH calibration curve. All samples were measured in triplicate. GSH synthetic rate was expressed as nmol of GSH/min/mg of protein.

\section{RNA extraction and RT-PCR determinations}

$\gamma$-GCS mRNA was determined by semi-quantitative RT-PCR in a Perkin-Elmer Gene Amp PCR System 2400 (Perkin Elmer, USA). Total RNA was obtained from PBMC lysed in the Ultraspec ${ }^{\text {TM }}$ RNA isolation system (Biotecx Laboratories, USA), and reverse transcribed as previously described (20). $0.3 \mu \mathrm{g}$ of cDNA was used for PCR amplification with specific primers which amplify a fragment 426 bp long from human hepatic $\gamma$-GCS gene (28), upstream primer $\left(5^{\prime}-3^{\prime}\right)$ d(AGA TGA TAG AAC TCG GGA GG) and downstrcam $\left(5^{\prime}-3^{\prime}\right)$ d(GCC TAT GTG GTG TTT GTG GGT). $\quad \gamma$-GCS cDNA fragments were amplified 26 cycles, a protocol that avoided interference of the plateau effect. As internal control for each sample, a fragment of $\beta$-actin cDNA was amplified (20). We have reported that $\beta$-actin mRNA expression does not change in liver or PBMC in CHC (20). PCR products were electrophoresed in $2 \%$ agarose gel stained with ethidium bromide. The bands obtained were analyzed with commercial software (Molecular Analyst/PC, Bio-Rad, ISA), $\gamma$-GCS mRNA values were normalized to those of $\beta$-actin mRNA and results were expressed as $\gamma$-GCS to $\beta$-actin ratio. Restriction enzyme digestion was performed to assess the specificity of the PCR reaction for the $\gamma$-GCS.

\section{Statistical analysis}

Data are presented as mean \pm standard error of the mean. Normality was assessed with the Shapiro-Wilks test. For normal distributions parametric tests were performed (Student $t$-test) and non-parametric analyses were performed in all other cases (Mann-Whitney, KruskallWallis). Outliers in normal populations were filtered with at least a 0.01 confidence interval. Associations between variables were studied with Pearson's correlation coefficient. All $p$-values were 2-tailed and were considered statistically significant when the associated probability was less than 0.05 . Statistical analysis was performed with the SSPS for Windows (6.1.3 version).

\section{Results}

In CH-C patients ( $n=13)$ MDA levels in PBMC were significantly increased as compared to healthy subjects $(n=12) \quad(3.95 \pm 0.17$ vs. $3.25 \pm 0.14 \mu \mathrm{mol} / \mathrm{g}$ protein, $p<0.005$, Fig. 1). Table 1 shows the activities of antioxidant enzymes in PBMC from $\mathrm{CH}-\mathrm{C}$ patients and normal controls. A significant rise in Mn-SOD activity and a significant reduction in the activity of GST were found in HCV-infected individuals as compared with control subjects. The activities of catalase, GPX and GR were similar in patients and controls.

TABLE 1

Antioxidant enzyme activities in cytoplasmic extracts from PBMC in healthy controls and chronic hepatitis $\mathrm{C}$ (CH-C) patients

\begin{tabular}{llcll}
\hline & Healthy controls & CH-C & $p$-value \\
\hline Mn-SOD (U/g prot.) & $221 \pm 4^{*}(n=10)$ & $237 \pm 2(n=10)$ & $<0.005$ \\
Catalase (KU/g prot.) & $70.3 \pm 8.3(n=17)$ & $78.6 \pm 9.7(n=19)$ & ns \\
GPX (U/g prot.) & $509.3 \pm 26.3(n=16)$ & $431.2 \pm 35.5(n=18)$ & ns \\
GR (U/g prot.) & $143.1 \pm 1.2(n=10)$ & $146.3 \pm 2.6(n=12)$ & ns \\
GST (U/g prot.) & $281.8 \pm 3.3(n=9)$ & $264.2 \pm 5.9(n=10)$ & $<0.05$ \\
\hline
\end{tabular}

* Mean \pm SEM. 
Fig. 2. (A) Reduced glutathione (GSH) and (B) oxidized glutathione (GSSG) levels in peripheral blood mononuclear cells from chronic hepatitis $\mathrm{C}(\mathrm{CH}-\mathrm{C})$ patients and healthy controls (C).

Total glutathione in PBMC cytosols were comparable in HCV-infected patients $(n=29)$ and in normal individuals $(n=35)(46.5 \pm 2.2$ vs. $51.9 \pm 1.9 \mathrm{nmol} / \mathrm{mg}$ protein, ns). The values of GSH and GSSG in PBMC, as estimated by HPLC, were also not significantly different in patients $(38.8 \pm 2$ and $2.4 \pm 0.1 \mathrm{nmol} / \mathrm{mg}$ protein, $n=14)$ and healthy controls $(42.4 \pm 1.3$ and $0.3 \pm 0.2 \mathrm{nmol} / \mathrm{mg}$ protein, $n=10$ ) (Fig. 2). Despite the absence of statistical significance, there was a tendency to lower GSH values and higher GSSG in HCV infection than in normal subjects, with about one third of patients exhibiting GSSG concentrations above the upper limit of normal values and GSH values below the lower limit of normal controls (Fig. 2). Interestingly, those patients who showed elevated GSSG values had, as compared to healthy controls, decreased GSH levels $(42.4 \pm 1.3$ vs. $34.0 \pm 3.6 \mathrm{nmol} / \mathrm{mg}$ protein, $p<0.05$ ).

GSH synthesis by purified PBMC cytosol was studicd in 27 healthy controls and 21 patients with $\mathrm{CH}$ C. The rate of GSH production in samples from normal individuals was $1.74 \pm 0.34 \mathrm{nmol} / \mathrm{mg}$ protein $/ \mathrm{min}$, the rate of synthesis was not affected by age or sex of the subject (data not shown). In PBMC from healthy controls, the GSH synthesis rate significantly correlated with the total GSH content $(r=0.51, n=27$, $p<0.01)$, and reduced GSH levels $(r=0.98, n=5$, $p<0.005$ ). HCV-infected patients showed a significant
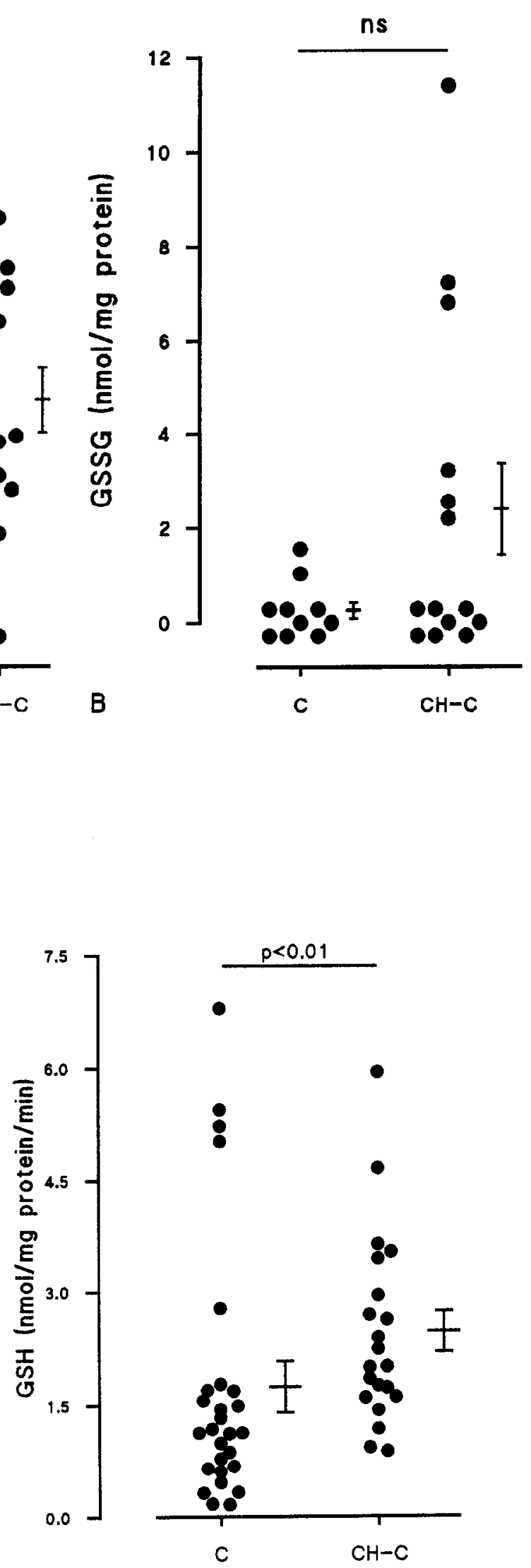

Fig. 3. Capability of glutathione (GSH) synthesis in peripheral blood mononuclear cells from chronic hepatitis $C$ (CH-C) patients and healthy controls $(\mathrm{C})$. 
increase in GSH synthesis rate in PBMC as compared to controls $(2.47 \pm 0.27$ vs. $1.74 \pm 0.34 \mathrm{nmol} / \mathrm{mg}$ protein/ min, $p<0.01$, Fig. 3). Interestingly, patients who did not respond to IFN treatment had an even higher $\mathrm{GSH}$-synthesis rate $(2.70 \pm 0.44$ vs. $1.74 \pm 0.34 \mathrm{nmol} / \mathrm{mg}$ protein/min, $p<0.001$, non-responders and controls, respectively), and in these cases the levels of $\gamma$-GCS mRNA in PBMC were significantly higher than in controls $(0.62 \pm 0.03$ vs. $0.53 \pm 0.02, p<0.05)$. In patients with $\mathrm{CH}-\mathrm{C}$, no significant correlation was found between GSH values and GSH synthesis rate.

We found no correlation between the oxidative stress parameters studied in PBMC and the HCV-RNA titer or the aminotransferases levels in serum.

\section{Discussion}

Our results show that PBMC from patients with $\mathrm{CH}$ $\mathrm{C}$ have increased MDA concentrations and enhanced SOD activity. MDA is a reflection of lipid peroxidation and SOD is an important antioxidant defense enzyme that converts superoxide into hydrogen peroxide. Increased SOD activity appears to be an adaptive response to increased generation of superoxide ions (29). Thus, our findings support the existence of oxidative stress in PBMC from patients with chronic $\mathrm{HCV}$ infection and are in agreement with previous data from our group showing increased Mn-SOD mRNA values in PBMC from these patients (16).

One of the factors, which may be responsible for oxidative stress in HCV infection, is the increased production of proinflammatory cytokines reported to occur in this condition. Raised serum tumor necrosis factor alpha (TNF-alpha) and increased TNF-alpha mRNA values in PBMC have been found in subjects with chronic HCV infection (20). TNF-alpha causes increased production of superoxide in mitochondria $(30,31)$ and induces, both directly and indirectly, $\mathrm{Mn}$ SOD upregulation $(32,33)$. In addition to inflammatory mediators, oxidative stress can also be produced as a direct consequence of viral replication. In this respect it should be considered that HCV infects not only hepatocytes but also lymphocytes and monocytes $(14,16,34)$, and thus it can cause direct cytopathic effects in the liver as well as in lymphoid cells.

SOD dismutates superoxide to hydrogen peroxide and this compound is catabolized by catalase and GPX. The latter two enzymes and also GR, which reduces GSSG to GSH, show normal values in PBMC from $\mathrm{CH}-\mathrm{C}$ patients. However, although these enzymatic activities are not significantly decreased, the adaptive antioxidant response of SOD is not concomitantly accompanied by GPX and/or catalase upregulation. Several studies have suggested that, to avoid lipid peroxidation, increased SOD activity should be accompanied by a rise in GPX activity (SOD/GPX ratio) (35-40). In consequence, an unbalanced antioxidant response could contribute to lipid peroxidation in chronic hepatitis $\mathrm{C}$. Another factor that might participate in causing lipid peroxidation is the decrease in glutathione S-transferase observed in cases with $\mathrm{HCV}$ infection. GSTs are a family of antioxidant and detoxification enzymes, which account for the non-seleniumcontaining glutathione peroxidase activity (4). Thus, reduced GST activity may diminish the efficacy of an enzymatic function that is critical in the protection of cell membranes, neutralizing lipid peroxides using GSH as cofactor $(7,41)$. The mechanisms responsible for reduced GST activity in HCV infection were not investigated in the present study. However, it has been reported that some viral proteins such as SV40 T antigen and adenovirus E1A have the ability to down-regulate the endogenous expression of glutathione S-transferase, an effect which has been thought to contribute to their carcinogenic potential (42). On the other hand, decreased GST activity is also found in the liver from HBV (hepatitis B virus)-infected patients, and the activity is further decreased during hepatocellular tumorogenesis, suggesting that cellular protection within the human liver is compromised in HBV-infected individuals (43). $\mathrm{HCV}$ also causes carcinogenesis, not only in the liver (44) but also in the lymphoid system (45). It is thus possible that reduced GST activity might play a role in various cytopathic effects exerted by HCV.

Glutathione plays a pivotal role in the defense against oxidative insult, as a cofactor of glutathione peroxidases (selenium dependent and independent) participates in the elimination of hydrogen peroxide and lipid hydroperoxides $(4,5,7)$. Our findings of high MDA values and high SOD activity in CH-C seem to indicate increased consumption of GSH in this condition. This increased consumption appears to be compensated by an increased GSH production, to maintain normal or quasi-normal GSH levels. In fact, in the present study we observed enhanced GSH synthetic capacity in patients with $\mathrm{CH}-\mathrm{C}$, especially in those who did not respond to IFN therapy. Interestingly, in these cases the mRNA levels of $\gamma$-GCS, a critical enzyme in the GSH synthesis, were significantly increased as compared to healthy controls. It should be noted, however, that despite increased GSH synthetic capacity, about one third of the patients showed levels of GSH below the lower limit of control values and GSSG concentration above the upper limit of controls.

To our knowledge the present report is the first to analyze GSH biosynthetic capacity in human cells. Interestingly, our results are similar to those of Fernán- 
dez-Checa \& Kaplowitz in isolated rat hepatocytes (27). In our study, PBMC cytosolic fraction was concentrated and glutathione-depleted to avoid feedback inhibition by the final reaction product. These experimental conditions allowed us to determine maximum GSH synthesis. Our results in healthy subjects showed that GSH biosynthetic capacity correlated significantly with total and reduced GSH content. However, this correlation is lost in patients, probably because in addition to biosynthetic capacity, other factors, such as increased GSH consumption, are influencing intracellular glutathione stores.

Taken together, our data indicate the presence of oxidative stress and an adaptive antioxidant response in PBMC from CH-C patients. The defensive antioxidant response includes high SOD activity and increased GSH biosynthetic activity. Despite activation of GSH biosynthesis, GSH remain within or below normal values, indicating increased GSH turnover. Oxidative stress may affect the efficiency of the effector mechanisms of the immune response (39), and it has also been shown to make cells more susceptible to apoptosis (46). It is possible, therefore, that oxidative stress in lymphoid cells may impair the antiviral immune response, thus facilitating chronicity of $\mathrm{HCV}$ infection.

\section{Acknowledgements}

This work was supported by grants PM95-0205 from CICYT (Spain) and 1852-95 from Gobierno de Navarra (Spain). P. Boya was financially supported by a grant from Gobierno de Navarra (Spain). We thank Carmentxu Miqueo for helpful technical assistance and Maria García for discussion and comments.

\section{References}

1. Meister A, Anderson M. Glutathione. Ann Rev Biochem 1983; 52: $711-60$.

2. Dröge W, Schulze-Osthoff K, Mihm S, Galter D, Schenk H, Eck HP, et al. Functions of glutathione and glutathione disulfide in immunology and immunopathology. FASEB J 1994; 8: 1131-8.

3. Nakamura $H$, Nakamura K, Yodoi J. Redox regulation of cellular activation. Ann Rev Immunol 1997; 15: 151-69.

4. Rushmore TH, Pickett CB. Glutathione S-transferases: structure, regulation, and therapeutic implications. J Biol Chem 1993; 268: 11475-88.

5. Sies H. Strategies of antioxidant defense. Eur J Biochem 1993; 215: 213-9.

6. Habig WH, Pabst MJ, Jakoby WB. Glutathione S-transferases. The first enzymatic step in mercapturic acid formation. J Biol Chem 1974; 249: 7130-9.

7. Spitz DR, Sullivan SJ, Malcolm RR, Roberts RJ. Glutathione dependent metabolism and detoxification of 4-hydroxy-2-nonenal. Free Radic Biol Med 1991; 11: 415-23.

8. Koziel MJ. Immunology of viral hepatitis. Am J Med 1996; 100: 98-109.

9. De Maria N, Colantoni A, Fagiuoli S, Liu GJ, Rogers BK, Farinati $F$, et al. Association between reactive oxygen species and dis- ease activity in chronic hepatitis C. Free Radic Biol Med 1996; 21: $291-5$

10. Farinati F, Cardin R, De Maria N, Della-Libera G, Marafin C, Lecis $\mathrm{E}$, et al. Iron storage, lipid peroxidation and glutathione turnover in chronic anti-HCV positive hepatitis. J Hepatol 1995; 22: 449-56.

11. Farinati F, Cardin R, D'Errico A, De Maria N, Naccarato R, Cecchetto A, ct al. Hepatocyte proliferative activity in chronic liver damage as assessed by the monoclonal antibody MIB1 Ki67 in archival material: the role of etiology, disease activity, iron, and lipid peroxidation. Hepatology 1996; 23: 1468-75.

12. Paradis V, Mathurin $P$, Kollinger $M$, Imbert-Bismut $F$, Charlotte F, Piton A, et al. In situ detection of lipid peroxidation in chronic hepatitis C: correlation with pathological features. J Clin Pathol 1997; 50: 401-6.

13. Beloqui O, Prieto J, Suárez M, Gil B, Qian CH, García N, et al. $\mathrm{N}$-acetyl cysteine enhances the response to interferon-alpha in chronic hepatitis C: a pilot study. J Interferon Res 1993; 13: 279 82.

14. Gil B, Qian C, Riezu-Boj JI, Civeira, MP, Prieto J. Hepatic and extrahepatic HCV RNA strands in chronic hepatitis C: different patterns of response to interferon treatment. Hepatology 1993; 18: $1050-4$.

15. Bronowicki JP, Loriot MA, Thiers V, Grignon Y, Zignego AL, Brechot $C$. Hepatitis $C$ virus persistence in human hematopoietic cells injected into SCID mice. Hepatology 1998; 28: 211-8.

16. Larrea E, Beloqui O, Muñoz-Navas MA, Civeira MP, Prieto J. Superoxide dismutase in patients with chronic hepatitis $\mathrm{C}$ virus infection. Free Radic Biol Med 1998; 24: 1235-41.

17. Sarobe P, Jauregui JI, Lasarte JJ, Garcia N, Civeira MP, BorråsCuesta, et al. Production of interleukin-2 in response to synthetic peptides from hepatitis $C$ virus $E 1$ protein in patients with chronic hepatitis $\mathrm{C}$ : relationship with the response to interferon treatment. J Hepatol 1996; 25: 1-9.

18. Lasarte JJ, García-Granero M, López A, Casares N, García N, Civeira MP, et al. Cellular immunity to hepatitis $\mathrm{C}$ virus core protein and the response to interferon in patients with chronic hepatitis C. Hepatology 1998; 28: 815-22.

19. Gavier B, Martinez-González MA, Riezu-Boj JI, Lasarte JJ, Garcia N, Civeira MP, et al. Viremia after one month of interferon therapy predicts treatment outcome in patients with chronic hepatitis C. Gastroenterology 1997; 113: 1647-53.

20. Larrea E, García N, Qian C, Civeira MP, Prieto J. Tumor necrosis alpha gene expression and response to interferon in chronic hepatitis C. Hepatology 1996; 23: 210-7.

21. Schreiber C, Matthias P, Muller MM, Schaffner W. Rapid detection of octamer binding proteins with mini-extracts prepared from a small number of cells. Nucleic Acids Res 1990; 17: 6419_ 22.

22. Castilla-Cortázar I, García M, Muguerza B, Quiroga J, Pérez R, Santidrián $\mathrm{S}$, et al. Hepatoprotective effects of insulin-like growth factor $I$ in rats with carbon tetrachloride-induced cirrhosis. Gastroenterology 1997; 113: 1682-91.

23. Goth $L$. A simple method for determination of serum catalase activity and revision of reference range. Clin Chim Acta 1991; 196: 143-51.

24. Tietze F. Enzymic method for quantitative determination of nanogram amounts of total and oxidized glutathione: applications to mammalian blood and other tissues. Anal Biochem 1969; 27: $502-22$.

25. Reed DJ, Babson JR, Beatty PW, Brodie AE, Ellis WW, Potter DW. High-performance liquid chromatography analysis of nanomole levels of glutathione, glutathione disulfide, and related thiols and disulfides. Anal Biochem 1980; 106: 55-62.

26. Fariss MW, Reed DJ. High-performance liquid chromatography of thiols and disulfides: dinitrophenol derivatives. Methods Enzymol 1987; 143: 101-9.

27. Fernández-Checa JC, Kaplowitz N. The use of monochlorobimane to determine hepatic GSH levels and synthesis. Anal Biochem 1990; 190: 212-9. 
28. Gipp JJ, Chang C, Mulcahy RT. Cloning and nucleotide sequence of a full-length cDNA for human liver gamma-glutamylcysteine synthetase. Biochem Biophys Res Commun 1992; 185: 29-35.

29. Wong GH, Elwell JH, Oberley LW, Goeddel DV. Manganous superoxide dismutase is essential for cellular resistance to cytotoxicity of tumor necrosis factor. Cell 1989; 58: 923-31.

30. Camussi G, Albano E, Tetta C, Bussolino F. The molecular action of tumor necrosis factor-alpha. Eur J Biochem 1991; 202: 3 14.

31. Murphy HS,. Shayman JA, Till GO, Mahrougui M, Owens CB, Ryan US, et al, Superoxide responses of endothelial cells to C5a and TNF-alpha: divergent signal transduction pathways. Am J Physiol 1992; 263: L51-9.

32. Warner BB, Stuart L, Gebb S, Wispe JR. Redox regulation of manganese superoxide dismutase. Am J Physiol 1996; 271: L150 8.

33. Röhrdanz E, Kahl R. Alterations of antioxidant enzyme expression in response to hydrogen peroxide. Free Radic Biol Med 1998; 24: 27-38.

34. Qian C, Camps J, Maluenda MD, Civeira MP, Prieto J. Replication of hepatitis $\mathrm{C}$ virus in peripheral blood mononuclear cells Effect of alpha-interferon therapy. J Hepatol 1992; 16: 380-3.

35. Ceballos-Picot I, Nicole A, Briand P, Grimber G, Delacourte A, Defossez A, et al Neuronal-specific expression of human copperzinc superoxide dismutase gene in transgenic mice: animal model of gene dosage effects in Down's syndrome. Brain Res 1991; 552: 198-214.

36. Amstad P, Moret R, Cerutti P. Glutathione peroxidase compensates for the hypersensitivity of $\mathrm{Cu}, \mathrm{Zn}$-superoxide dismutase overproducers to oxidant stress. J Biol Chem 1994; 269: 1606-9.

37. Peled-Kamar M, Lotem J, Okon E, Sachs L, Groner Y. Thymic abnormalities and enhanced apoptosis of thymocytes and bone marrow cells in transgenic mice overexpressing $\mathrm{Cu} / \mathrm{Zn}$-superoxide dismutase: implications for Down syndrome. EMBO J 1995; 14: 4985-93.

38. Zhong W, Oberley LW, Oberley TD, Yan T, Domann FE, St. Clair DK. Inhibition of cell growth and sensitization to oxidative damage by overexpression of manganese superoxide dismutase in rat glioma cells. Cell Growth Differ 1996; 7: 1175-86.

39. De-Haan JB, Wolvetang EJ, Cristiano F, Iannello R, Bladier C, Kelner $\mathbf{M}$, et al. Reactive oxygen species and their contribution to pathology in Down syndrome. Adv Pharmacol 1997; 38: 379-402.

40. Keller JN, Kindy MS, Holtsberg FW, St-Clair DK, Yen HC, Germeyer A, et al. Mitochondrial manganese superoxide dismutase prevents neural apoptosis and reduces ischemic brain injury: suppression of peroxynitrite production, lipid peroxidation, and mitochondrial dysfunction. J Neurosci 1998; 18: 687-97.

41. Gopalakrishnan B, Shaha C. Inhibition of sperm glutathione Stransferase leads to functional impairment due to membrane damage. FEBS Lett 1998; 422: 296-300.

42. Sompayrac L. SV40 and adenovirus may act as cocarcinogens by downregulating glutathione S-transferase expression. Virology 1997; 233: 130-5.

43. Zhou T, Evans AA, London WT, Xia X, Zou H, Shen F, et al. Gluathione S-transferase expression in hepatitis B virus, associated human hepatocellular carcinogenesis. Cancer Res 1997; 57: 2749-53.

44. Ruiz J, Sangro B, Cuende JI, Beloqui O, Riezu-Boj JI, Herrero JI, et al. Hepatitis B and C viral infections in patients with hepatocellular carcinoma. Hepatology 1992; 16: 637-41.

45. Zuckerman E, Zuckerman T, Levine AM, Douer D, Gutekunst $\mathrm{K}$, Mizokami $\mathbf{M}$, et al. Hepatitis $\mathrm{C}$ virus infection in patients with B-cell non-Hodgkin lymphoma. Ann Intern Med 1997; 127: 423-8.

46. Buttke TM, Sandstrom PA. Oxidative stress as a mediator of apoptosis. Immunol Today 1994; 15: 7-10. 